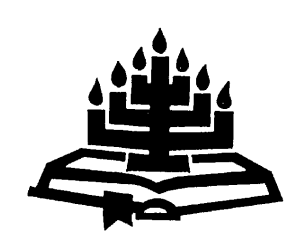

\title{
Die noodsaak van die verrekening van metateoretiese vertrekpunte in prakties- teologiese wetenskapsbeoefening
}

\author{
F.W. de Wet \\ Skool vir Kerkwetenskappe \\ Potchefstroomkampus \\ Noordwes-Universiteit \\ POTCHEFSTROOM \\ E-pos: fritz.dewet@nwu.ac.za
}

\author{
H.J.C. Pieterse \\ Praktiese Teologie \\ Universiteit van Suid-Afrika \\ \& buitengewone professor \\ Universiteit van Pretoria \\ PRETORIA \\ E-pos: pietehjc@absamail.co.za
}

\begin{abstract}
The necessity of reckoning with metatheoretical assumptions in scientific practical-theological research

This article is the first in the research project "Metatheoretical assumptions in Practical Theology". The research problem has to do with the lack of explicit expression of metatheoretical assumptions against the background of a plurality in scientific approaches to the discipline. Sometimes researchers do not explicity state their theological and other approaches. In this project a group of reformed practical theologians explicitly state their metatheoretical theological and other perspectives and explain their vantage points in researching the praxis. The necessity to explain metatheoretical assumptions pertaining to the assumptions about reality, the hermeneutical process in understanding, explaining and changing actions in praxis, and the nature and task of scientific research, is discussed from a reformed perspective.
\end{abstract}

\section{Opsomming}

Die noodsaak van die verrekening van metateoretiese vertrekpunte in prakties-teologiese wetenskapsbeoefening

Hierdie artikel is die eerste resultaat van die navorsingsprojek "Metateoretiese vertrekpunte in Praktiese Teologie". Die probleem wat ondersoek word, het te make met 'n gebrek aan deursigtigheid met betrekking tot die uitspel van metateoretiese vertrekpunte teen die agtergrond van die pluraliteit in die benaderings tot die navorsing in die vak. Soms verklaar na- 
vorsers nie hulle teologiese en ander vertrekpunte nie. In hierdie projek word die metateoretiese teologiese en ander vertrekpunte van 'n groep reformatoriese navorsers eksplisiet gemaak en die invalshoeke in die ondersoek van die praksis aangetoon. Die noodsaak om metateoretiese vertrekpunte uit te spel ten opsigte van werklikheidsbeskouing, die hermeneutiese proses wanneer handelings in die praksis verstaan, verklaar en verander word en die beskouing van die aard en taak van wetenskapsbeoefening, word vanuit 'n reformatoriese perspektief behandel.

\section{Inleiding}

Die praktiese teoloë van die Skool vir Kerkwetenskappe aan die Noordwes-Universiteit (Potchefstroomkampus) in samewerking met H.J.C. Pieterse van die Departement Praktiese Teologie aan Unisa en buitengewone professor aan die Universiteit van Pretoria is besig met 'n projek oor die voorvrae van prakties-teologiese ondersoek, naamlik die metateoretiese vertrekpunte oor die breë veld van die vak. Die projek staan bekend as "Metateoretiese vertrekpunte in Praktiese Teologie". Hierdie artikel is die eerste artikel in die projek wat as 'n oorsig dien van sake wat ter sprake kom in die ondersoek.

Die oorhoofse probleemstelling raak verskeie aspekte van die saak aan en lui soos volg: In 'n tyd waarin die pluraliteit wat deur postmoderniteit oopgemaak is tot 'n groot mate steeds invloed uitoefen, is dit opvallend hoeveel diversiteit daar in verskillende benaderingswyses tot prakties-teologiese wetenskapsbeoefening is. Die uitwerking van diversiteit word gekompliseer deur die verskynsel dat navorsers nie altyd die teologies-teoretiese raamwerk waarin hulle vooronderstellings ingebed is, uitdruklik uitspel nie. Gevolglik kan 'n gebrek aan deursigtigheid met betrekking tot metateoretiese vertrekpunte ontstaan (vgl. Pieterse, 2010).

In sosiologiese navorsing werk sommige skrywers met 'n postmoderne interpretasie van die sogenaamde abduction-idee wat daarop neerkom dat 'n navorser die ondersoekveld met oop, onbevange denke kan benader sonder om deur teoretiese veronderstellings in een of ander rigting gestuur te word (vgl. Reichertz, 2004; Bude, 2004). Die problematiek wat in 'n pluralistiese situasie kan ontstaan ten opsigte van prakties-teologiese wetenskapsbeoefening is meervoudig:

- In 'n see van moontlikhede is dit vir 'n navorser baie moeilik om hom-/haarself te oriënteer ten opsigte van die navorsingsveld. Aspekte soos verantwoordbaarheid, bakens vir konsekwentheid 
in die rigting wat ingeslaan word, en inagneming van alle faktore wat relevant mag wees, kan in die gedrang kom.

- 'n Verdere problematiese aspek van die "inplons-en-swem"-styl van wetenskapsbeoefening is dat lesers aan wie navorsingsresultate gekommunikeer word, in die duister verkeer ten opsigte van die teologies-teoretiese raamwerk wat onderliggend is aan dit wat op die oppervlakte gesien word. Sonder insig in die navorser se teologies-teoretiese raamwerk, is dit baie moeilik om 'n greep te kry op waarom hy/sy met 'n bepaalde invalshoek werk en hoe hy/sy by 'n bepaalde punt uitgekom het. Sodoende is die proses om deur die betrokke navorsingsresultate oortuig te word baie moeilik.

Die dinamika van bogenoemde problematiek kan geïllustreer word deur te verwys na 'n saak, wat in die reformatoriese tradisie waarin ons staan, nog altyd belangrik was, naamlik die sola Scriptura-benadering. Wanneer daar 'n gebrek is aan 'n uitdruklike uitspel van die onderliggende teologies-teoretiese raamwerk waarmee die navorser werk, kan verantwoording ten opsigte van die sola Scripturagedagte só op die agtergrond vervaag, dat die Skrif vir alle praktiese doeleindes as 'n beperkte normatiewe bron met slegs relatiewe betekenis hanteer word. Aan die ander kant van die spektrum kan 'n ondeurdagte en oorvereenvoudigde hantering van die sola Scriptura-benadering tot die verengende raamwerk van fundamentalisme en biblisisme aanleiding gee. Die Skrif word dan op 'n a-historiese, kliniese manier hanteer, waarin dit - dikwels ter wille van konservering van die Skrifgebruiker se magsposisie - geïsoleer word van die werklikhede waarop dit lewensvernuwend in die kontemporêre konteks gerig moet word.

In hierdie navorsingsprojek wil 'n saak uitgemaak word vir die noodsaak daarvan om die eie metateoretiese vertrekpunte met diepgaande verantwoordelikheid te verreken en duidelik te kommunikeer in prakties-teologiese wetenskapsbeoefening.

Wat word met metateoretiese vertrekpunte bedoel? Osmer (2008: 58) formuleer sy definisie van metateorie in die konteks van die krisis wat in die empiriese navorsing van die sosiale wetenskappe ontstaan het ten opsigte van die representatiewe akkuraatheid van "feite", wat na aanleiding van direkte waarneming van die werklikheid vasgestel word. Die krisis het ontstaan weens die insig dat dit nie langer aanvaar kan word dat feite deur direkte waarneming van die werklikheid vasgestel kan word nie. Waarneming is belaai met 'n onderliggende teorie en vooronderstellings en is afhanklik van be- 
paalde (ontwerpte) navorsingspraktyke en tegnologiese instrumente waardeur data versamel word. Dit maak 'n direkte ooreenkoms tussen ' $\mathrm{n}$ fenomeen en die wetenskaplike representasie daarvan problematies. Hierdie krisis het onder andere sosiale wetenskaplikes meer reflektief laat optree rakende die keuses en aannames wat 'n rol kan speel in die manier waarop hulle werk uitgevoer word. Wetenskaplikes het meer sensitief daarvoor geword om na te dink oor hoe hulle hulle eie perspektief rakende sleutelaspekte van die wetenskaplike proses aan ander moes kommunikeer. Vrae soos: "Wat is die aard van werklikheid?" (ontologie); "Hoe kan die werklikheid geken word?" (epistemologie); en "Wat is wetenskap?" (wetenskapsfilosofie) moes beantwoord word. Osmer (2008:58) definieer metateorie soos volg:

A metatheoretical perspective, thus is composed of the assumptions about reality, knowledge and science that transcends particular research projects and theories.

Wanneer aansluiting gevind word by hierdie omlyning van Osmer, sou verantwoording ten opsigte van metateoretiese vertrekpunte ten minste op drie vlakke moes plaasvind, naamlik

\section{- Ten opsigte van die implikasies van die onderliggende werklikheidsbeskouing waarmee gewerk word}

'n Navorser werk met 'n onderliggende werklikheidsbeskouing waarvolgens die gebeurlikheidsdimensie op die ondersoekterrein van Praktiese Teologie (op ontologiese vlak) in oënskou geneem word. $\mathrm{Hy} / \mathrm{sy}$ werk ook met 'n teologiese rasionaal vir hierdie bepaalde werklikheidsbeskouing (op epistemologiese vlak), wat in 'n groot mate bepalend is vir die manier waarop die ondersoekterrein benader sal word en volgens bepaalde kriteria geïnterpreteer sal word. Die handelingsveld wat ondersoek word (praksis) is ingebed in die gebeurlikheidsdimensie van die werklikheid. Die navorser se antwoorde op vrae soos "Waar kom die handelingspraksis wat waargeneem word vandaan?", "Wat is die wese van dit wat waargeneem word?", "In hoe 'n mate is die goddelike dimensie teenwoordig in dit wat waargeneem word?" en "Waarheen is dit wat waargeneem word op pad?", sal verteenwoordigend wees van 'n bepalende onderbou vir die invalshoek waarmee 'n navorsingsprojek aangepak word en die doelwitte waarop dit afgestuur word. 
- $\quad$ Ten opsigte van die onderliggende siening rondom die manier waarop die handelingspraksis wat ondersoek word, op 'n omvangryke en getroue manier verstaan kan word

Hier kom die hermeneutiese dimensie ter sprake. Elke navorser werk met 'n onderliggende beskouing rondom die manier waarop dit wat waargeneem word, op 'n geldige manier verstaan kan word. Sonder verantwoordbare hermeneutiese beginsels kan wanpersepsies ontwikkel, 'n eensydige verstaan ontstaan en kan voorstelle vir ' $n$ verandering in die praksis weens onkunde deformerend werk en ontaarding meebring. Hoe kan daar in die verstaan van die praksis 'n werklikheidsgetroue verhouding tussen die navorser en die ondersoekterrein tot stand gebring word sodat daar nie verengend, verarmend en manipulerend daarmee omgegaan word nie?

\section{- $\quad$ Ten opsigte van die onderliggende beskouing rondom die aard en taak van wetenskapsbeoefening}

Op hierdie vlak kom die onderliggende beskouing van die navorser rondom die aard en die taak van prakties-teologiese wetenskapsbeoefening na vore. Die antwoord van die navorser op die volgende vrae sal bepalend wees: "Waarin verskil prakties-teologiese wetenskapsbeoefening van die ander teologiese dissiplines?", "In hoe 'n mate het Praktiese Teologie te make met die ontwerp van teorieë rakende en vir praksis?", "In hoe 'n mate en op watter vlak vind Praktiese Teologie aansluiting by aangrensende wetenskappe wat ook menswees en menslike gedrag/handelings ondersoek?"

In hierdie inleidende artikel word oorsigtelik by wyse van kritiese literatuurondersoek aan bogenoemde drie aspekte aandag gegee in 'n poging om aan te dui hoe nodig dit is (vir die navorser self en ter wille van die mense wat van sy/haar navorsingsresultate kennis wil neem) om die metateoretiese vertrekpunte duidelik uit te spel in prakties-teologiese navorsing. Hierdie beredenering rondom die noodsaak van die uitspel van metateoretiese vertrekpunte, word aangevoer en geillustreer vanuit die reformatoriese benadering tot prakties-teologiese wetenskapsbeoefening.

In opvolgartikels sal indringende aandag gegee word aan bogenoemde drie aspekte van metateorie, voordat daartoe oorgegaan word om die waarde van die uitdruklike uitspel van die metateorie te illustreer deur spesifieke navorsingprojekte op die terrein van vakgebiede soos Homiletiek, Liturgiek en Pastorale wetenskap vanuit hierdie invalshoek aan te pak. 


\section{Verrekening van metateoretiese vertrekpunte ten opsigte van die werklikheidsbeskouing}

Sonder 'n uitdruklike verantwoording ten opsigte van die metateoretiese onderbou van die werklikheidsbeskoulike vertrekpunte waarmee gewerk word, kan die navorser ten opsigte van invalshoeke en die navorsingsdoel in ankerloosheid ronddryf. Newport (1998:40) wys op die integrale rol wat die werklikheidsbeskouing op die algemene persepsie en wetenskaplike aanpak van die waarnemer speel.

Each of us has a worldview, or vision, of life. It may or may not be organized, but it makes up a framework of fundamental considerations which give context, direction and meaning to our lives. What is new and remarkable today is our increasing awareness of how worldviews affect both our perceptions of the world and our actions. Conflicts in life and even in science, we are discovering, come down to differences in underlying worldviews.

Wanneer die werklikheid ondersoek word en daar verantwoordbare en geldige waarnemings gemaak wil word, moet 'n antwoord gevind word op die vraag na die aard van die werklikheid asook ten opsigte van die manier waarop die navorser se vooronderstellings die antwoord op hierdie vraag sou kleur. Vanuit fenomenologiese denke is aangetoon dat die konsep van die werklikheid nie op 'n oorvereenvoudigde manier benader kan word nie. Die werklike is nie bloot 'n objektiewe "daar-wees" in die sin van 'n onveranderlike syn nie. Aan die ander kant is die konstitusionele elemente waardeur ' $n$ werklikheidsbeskouing gevorm word ook nie bloot 'n produk van psigiese of geestelike prosesse wat in 'n mens afspeel, waardeur die ervaring van dit wat waargeneem word tot werklikheid gemaak word nie.

Konstitution ist vielmehr ein Wechselspeil zwischen Erkannten und Erkennendem, zwischen Erfahrenem un Erfahrendem, keiner 'Seite' eindeutig zuzuordnen, sondern sich in einem Zwischenraum abspielend. (Lotz, 2007:61.)

Wanneer die konstitusionele bepaaldheid van 'n navorser se werklikheidsbeskouing nie in ag geneem word nie en dit nie deur middel van kritiese introspeksie na die oppervlak gebring word en tot verantwoording geroep word nie, kan daar sprake wees van blikverenging, blindheid en ideologiese ingeperktheid (Drehsen, 2007: 184). 
Kragtens die aard van prakties-teologiese wetenskapsbeoefening is 'n navorsingprojek wat vanuit hierdie vakgebied onderneem word op die gebeurlikheidsdimensie in die waarneembare werklikheid van menslike handelings in die bepaaldheid daarvan deur die goddelike werking in die evangelie gerig. Die dilemma waarin die praktiese teoloog verkeer omdat hy/sy met die onsigbare, goddelike element agter die sigbare dimensie in sy/haar beskrywing en verklaring van die werklikheid rekening moet hou, word deur Viau (1999:83) soos volg beskryf:

When we speak of God, we know that this Real which we entertain is situated beyond human understanding. This real is a distant, invisible entity, whose power over the human being is demonstrated in a roundabout manner, at times imperceptibly. How can one speak then of the ineffable?

Sonder 'n weldeurdagte prakties-teologiese benadering waarin die goddelike betrokkenheid by die sigbare werklikheid van menslike handelings uiteengesit word, sou die unieke invalshoek wat nodig is vir 'n prakties-teologiese blik op die werklikheid wat waargeneem en ondersoek word, uit fokus raak. Die gebeurlikhede in die handelingsveld kan dan so antroposentries ingeklee word (bloot as aktualisering van menslike potensiaal), dat die skynbaar onsigbare teenwoordigheid van God op die agtergrond verdwyn en die teologiese kwaliteit van die studie in die gedrang kom.

Wanneer 'n prakties-teologiese navorsingsprojek vanuit die reformatoriese werklikheidsbeskouing aangepak word, sou die navorser hom/haar moet oriënteer ten opsigte van die manier waarop hierdie benadering sy vertrekpunt neem vanuit die normatiewe bron van die Skrif as middel waardeur God sy betrokkenheid in hierdie wêreld tot openbaring bring. Die teologiese rasionaal waarmee daar in 'n trinitaries-bepaalde werklikheidsbeskouing gewerk word, neem die vertrekpunt in die manier waarop God Hom in sy Woord openbaar as die Een wat in 'n skeppende, verlossende en vernuwende/voleindigende verhouding, op 'n relasionele wyse wat van verbondstrou getuig, met die werklikheid waarin ons leef, staan (vgl. Grenz, 2004; Van Pelt, 1999). Wanneer met hierdie vertrekpunt gewerk word, word menslike handelings wat in die handelingsveld waargeneem word, in die handelings van God geanker, of word beoordeel in hoe 'n mate die verhouding met God in menslike handelingspraksis versteur is. Omdat prakties-teologiese navorsing op die gebeurlikheidsdimensie fokus, sou nie alleen die ruimtelike nie, maar ook die tydsdimensie van die werklikheid in ag geneem moet word. Die handelings van God in verhouding met mense vind plaas in die 
dialektiek tussen die bestaande en die nog nie-bestaande elemente, wat kenmerkend is van die manier waarop die koninkryk van God na hierdie wêreld kom; in die temporele gebeurlikheidsveld van anamnese en antisipasie, van gedenk en verwag (vgl. Heitink, 1993:153). Die gebeurlikheidsdimensie van dit wat waargeneem word, word geanker in die God uit Wie, deur Wie, en tot Wie alle dinge is.

Hierdie bepaalde werklikheidsbeskouing sou egter voortdurend verantwoord moet word ten opsigte van kritiese vrae wat daaraan gestel sou kon word. Een van die vlakke waarop hierdie verantwoording sou moes plaasvind, is ten opsigte van die verhouding tussen die goddelike element en die menslike element van dit wat in die gebeurlikheidsdimensie van die werklikheid waargeneem word. 'n Voorbeeld van 'n ander belangrike aspek wat elders in hierdie reeks artikels ter sprake gebring sal word, is die vraag na die verhouding tussen afstand (transendensie) en nabyheid (immanensie) in die goddelike betrokkenheid by dit wat in die sigbare dimensie van die werklikheid waargeneem word (vgl. Baars, 2004).

Wat die verhouding tussen die goddelike en die menslike element betref, die volgende: Deur middel van kritiese introspeksie sou die navorser hom/haar moes verantwoord of ' $n$ teosentriese benadering nie die menslike element in sy/haar werklikheidsbeskouing onderontwikkeld laat nie. Daar sou 'n antropologiese versmalling kon plaasvind wanneer die mens en menslike handelings primêr tussen die pole van sonde en genade gesien word en die mens as skepsel sodanig agter die mens as sondaar sou kon verdwyn (vgl. Rebel, 1981:201). Daar sou in hierdie proses van kritiese introspeksie verwys kon word na Immink (2005:263) se beskouing rondom die struktuur van die verhouding tussen die goddelike subjek en die menslike subjek. Die struktuur van die geloofsverhouding met God, impliseer dat God 'n subjek van spreke en handeling is. God is ' $n$ intensionele Subjek wat Hom bewustelik op mense rig. Terselfdertyd rig mense hulle op God en ken hulle God. Daar is sprake van resiprositeit in hierdie verhouding, maar ook van asimmetrie. God is die Heilige en het die reg op prioriteit in die kommunikatiewe gebeure. Die mens wat pneumatologies vernuwe word na die beeld van Christus, is egter volledig 'n handelende subjek wat in geloof vrywillig op God se genade antwoord. 


\section{Verrekening van metateoretiese aspekte rakende die hermeneutiese proses in die prakties-teologiese ondersoek}

In hierdie afdeling word die outeurs se beskouing van die hermeneutiese proses in die prakties-teologiese ondersoek, oorsigtelik op metateoretiese vlak verantwoord. Dit is die hermeneutiese proses wat ter sprake kom in die verstaan, verklaar en verandering van ' $n$ bepaalde handelingsveld wat in die werklikheid van die praksis van die kerk en gelowiges waargeneem word. Saam met Osmer (2008) word gekies vir 'n oorkoepelende hermeneutiese benadering in die prakties-teologiese ondersoek in onderskeiding van 'n empiries-analitiese benadering (vgl. Van der Ven, 1990; 1993) en 'n bevrydingsteologiese benadering (vgl. Höfte, 1990; Cochrane et al., 1991). In die hermeneutiese benadering tot die vak staan die outeurs nie alleen nie, maar in ooreenstemming met Dingemans (1996), Heitink (1993), Browning (1991) en Osmer (2008).

Die hermeneutiese proses in die ondersoekproses by die verstaan van die praksis - binne die raamwerk van die verstaan van die huidige konteks en die bybelse teks, asook binne die huidige konteks en funksionerende teologiese teorie en haar tradisie - is deur die meeste praktiese teoloë gebruik in hulle proses van ondersoek. Dingemans (1996:55-56) praat van 'n uiteindelike integrasie in die benaderingswyses van die hermeneutiese en empiriese in ons vak. By die meeste ondersoekers word die resultate van empiriese ondersoek of sosiale analises en bestaande teorieë wat die huidige praksis rig, op 'n hermeneutiese wyse op mekaar betrek om tot 'n nuwe verstaan en insig te kom vir die ontwikkeling van nuwe praktykteorieë (vgl. byvoorbeeld Zerfass, 1974). In hierdie afdeling sal op die hermeneutiese aktiwiteit gekonsentreer word wanneer die insigte uit die bybelse tekste en teologiese teorieë met die resultate van die empiriese ondersoek van die praksis hermeneuties op mekaar betrek word.

Om egter die werklikheid van die handelings in die praksis te verstaan, is daar metateoretiese beslissings oor 'n hermeneutiese aanpak wat deur ' $n$ reformatoriese praktiese teoloog geneem behoort te word. Die aard van die werklikheid wat ons waarneem, is 'n werklikheid waarin God drie-enig werksaam is. Daarom is die invalshoek vir hierdie navorsing anders as die sosiale wetenskappe se invalshoeke. Die reformatoriese praktiese teoloog se invalshoek is vanuit 'n pneumatologiese perspektief (De Wet, 2009). Dit is ' $n$ belangrike insig om te weet dat die werklikheid van die praksis wat ons probeer 
verstaan, verklaar en verander 'n beweeglike en dinamiese werklikheid is. Uit die aangrensende wetenskappe van die Filosofie, die Sosiologie en die Historiese wetenskappe, leer ons dat die samelewing en selfs die religie voortdurend aan die verander is (vgl. Taylor, 2007; Van der Ven, 2010 vir hierdie hermeneutiese insig). Die handelings van 'n christelike geloofsgemeenskap wat hulle diens aan God op sekere wyses inrig, vloei voort uit 'n bepaalde historiese ontwikkeling wat gebaseer is op hulle teologiese tradisie, in hierdie geval die Reformasie. Die patrone van die handelings dui weer op die rigting waarheen die geloofsgemeenskap in die toekoms op pad is. Die kontemporêre rigting het te make met hulle verstaan van die Skrif en die prakties-teologiese teorie vir die bepaalde veld van bediening wat op daardie oomblik ten grondslag van hulle optrede lê. Die handelings kan bewustelik die teologiese onderbou volg, of dit kan selfs onbewustelik wees. Die metateoretiese insig van die dinamika en beweeglikheid wat die geloofshandelings van 'n christelike geloofsgemeenskap ten grondslag lê, is noodsaaklik vir ons waarneming en interpretasie van dit wat aan die gang is. Die beweeglikheid het onvermydelik ook 'n spanning tussen idees en samelewingsfaktore ten grondslag.

Vir 'n goeie hermeneutiese interpretasie van die praksis is die metateoretiese hermeneutiese benadering van die spanningsveld tussen motiewe vir die behoud van die status quo, en motiewe vir die vernuwing van die status quo, soos byvoorbeeld die inrigting van die erediens, noodsaaklik. Trouens, dit is die hart van 'n hermeneutiese proses, omdat hermeneuse in die verstanende heen-en-weer konfrontasie geskied van die spanning tussen die bybelse teks en die huidige konteks, tussen teorie en praksis, en tussen behoudendheid en vernuwing in die praksis van die kerk. Dit is dus noodsaaklik om hier as metateorie 'n geskikte hermeneutiese benadering vir die spanningsvelde in gebruik te neem. Ons vind dit in Ricoeur se dialektiese hermeneutiese metode (vgl. Ricoeur, 1976a; 1992). Aangaande teologiese normatiwiteit in die spanning tussen tradisionalisme en vernuwing, neem hy die ekstreme konsepte van ideologie en utopie ter hand (vgl. Dreyer, 2002:4). Die dialektiese spanning gaan oor die vraag na die normatiewe identiteit van 'n kerklike geloofsgemeenskap. Ricoeur plaas hierdie dialektiek binne sy teorie van kulturele verbeelding (cultural imagination). In die dialektiese heen-en-weer tussen die twee ekstreme standpunte is daar kritiek op albei. Die kritiese heen-en-weer in die verstaansproses lei tot die insig dat ekstreme konserwatisme wat nie rekening hou met die konteks nie (soos dit byvoorbeeld in fundamentalisme tot uitdrukking kom), verhard tot 'n ideologie; ook dat ekstreme vernuwing wat nie 
rekening hou met die konteks en die normatiewe identiteit van die geloofsgemeenskap nie, vervlugtig tot 'n utopie (Ricoeur, 1976a). Deur die gespreksmetode van die dialektiese hermeneutiese aanpak kan dus van albei kante geleer word om uiteindelik tot 'n sinvolle standpunt te kom, getrou aan die normatiewe identiteit en die kontemporêre konteks waarin die gemeente die Here dien.

'n Verdere hermeneutiese metateoretiese beslissing wat die praktiese teoloog moet neem, is die vraag na die instrumente wat gebruik moet word om die komplekse teks van die handelingsveld op 'n verantwoordbare, werklikheidsgetroue wyse waar te neem en te verstaan. Die verwysing is na die komplekse konteks van die handelingsvelde in die bediening van die evangelie as 'n lewende teks. Ricoeur gaan daarvan uit dat die huidige konteks ook as 'n teks gesien moet word (Ricoeur, 1976b). Die handelingsveld moet waargeneem word vanuit die beoordeling van watter teologiese tradisie en interpretasie van die Skrif in hierdie tradisie, die motiewe vir die bepaalde optrede is. Met die resultate van die empiriese ondersoeke van die handelings in konteks, sal die Skrif interpreterend as kriterium aangelê moet word vir die strategiese voorstelle van die rigting waarin die geloofsgemeenskap in die toekoms moet ontwikkel. Dit beteken, Skrifgetrouheid en relevansie in die samelewing en die konteks waarbinne die gemeente leef en werk. In die hermeneutiese proses moet daar interaksie wees tussen Skrif, teologiese tradisie, empiriese resultate van die ondersoek in die spesifieke handelingsveld en die insigte wat aangrensende wetenskappe bydra tot die verstaan van die kultuur en die huidige lewensgevoel. Wat die lewensgevoel tans betref oor die omgang van mense met mekaar, asook in navorsingsprojekte, kan van Taylor (2007) geleer word. Hy skryf dat die mens van ons tyd altyd met respek, menswaardigheid en erkenning behandel wil wees (respect, human dignity, recognition).

Ware vernuwing en verandering van die praksis in die normatiefhermeneutiese dimensie in die navorsingsproses wat ten goede as veranderingstrategie werk, kan alleen deur God se werking in die lewens van die gemeente en die ondersoeker plaasvind. God is besig om deur sy Woord en Gees in die geloofslewe van mense te werk. Sy genade, deur die werking van die Gees in ons lewens, inisieer die verandering ten goede. Die uitverkiesende liefde van God is die bron van verandering. God open ons verstand deur sy Gees, deurdat mense beweeg word om vernuwend diensbaar aan God en die medemens te wees (De Wet, 2009:247). Immink se idee van 'n bipolêre spanning tussen God se aktiwiteit en die mens se 
aktiwiteit vanuit sy konsep van die geloofsverhouding tussen God en die mens, is hier van toepassing (vgl. Immink, 2003).

Die aard van die hermeneutiese proses wat ons gebruik, vra ook 'n metateoretiese beslissing. Ons maak die keuse vir die hermeneutiese teorie van Gadamer (1975; 1979). Die mens se kontekstuele bestaan in die wêreld is die basiese voorwaarde van elke wyse om te ken en betekenis aan sy/haar omgewing te kan gee. Elke mens het 'n eie verstaanshorison en 'n voorverstaan in die vorm van vooroordele (Gadamer, 1975:261-268; 1979:245-253). Die verstaansproses verloop soos volg: Ons moet ons vooroordele, ons voorverstaan (dit is ons siening van sake en die geloofsverstaan van die eie tyd) doelbewus in die verstaansproses inbring. Ons moet onthou dat die verbinding met die verlede van byvoorbeeld die Skrif, of bepaalde tekste in die Skrif, in die konsep van die Wirkungsgeschichte lê. Dit is die interpretasiegeskiedenis en die deurwerking van die tradisie tot vandag toe (Gadamer, 1975:284-290; 1979:267-274).

In die dialogiese wisselwerking tussen die horison van byvoorbeeld die bybelse teks of die saak wat interpreteer word en die horison van die interpreteerder vind ' $n$ kritiese konfrontasie plaas. Dit geskied in die vorm van afstand en nabyheid, vervreemding en deelname (Gadamer, 1975:275-282; 1979:258-265). Die teks van die Skrif of voorwerp van ondersoek, stel kritiese vrae aan die hermeneut se voorverstaan indien hy/sy op hierdie wyse in die kritiese dialoog met die verskillende horisonne van verstaan betrokke raak.

Dit is juis in hierdie heen-en-weer van die interpreterende konfrontasie tussen waarnemer en teks van die Skrif of die praksis waarin verstaan uiteindelik daag. Dit is ' $n$ taalgebeurtenis wat hier geskied, want uiteindelik word die teks ook subjek sodat daar 'n subjeksubjekverhouding ontstaan - die teks begin te spreek. Verstaan geskied vir die mens alleenlik deur taal - en veral taal as gesprek (Gadamer, 1975:344-360; 1979:325-341).

Die hermeneutiese spanning tussen die eie en die vreemde horisonne, dialogies verwerk deur die verstaansproses heen, bewerk 'n horisonsversmelting waarin verstaan van die teks se betekenis vir die eie tyd kan geskied (Gadamer, 1975:289-290, 356-366; 1979: 274-276, 333-341). Nuwe insig word verkry en albei horisonne dra iets by tot die nuwe Einverständnis.

Die gevolg van die intensiewe, betrokke verstaansproses se verloop is gewoonlik nuwe insigte vanuit die teks (of voorwerp van ondersoek) en 'n nuwe kyk op die eie konteks. Nuwe insigte gee aan- 
leiding tot nuwe maniere van dink en optrede in die wêreld. Die verstaansproses soos hierbo aangestip, het implikasies vir ons hermeneutiese omgang met die komplekse teks van die handelingspraksis wat ons ondersoek. Dialogiese wisselwerking kenmerk ons ondersoekprosesse van verstaan, verklaar en die strategie vir verandering.

\section{Verrekening van metateoretiese aspekte rakende die wese en taak van prakties-teologiese wetenskaps- beoefening}

Dit is belangrik om op metateoretiese vlak 'n beslissing te maak oor die verhouding tussen teorie en praksis in 'n prakties-teologiese ondersoek. Die teorie-praksisverhouding is die hart van die praktiesteologiese wetenskapsteoretiese beginsels. Praktiese Teologie as wetenskap het 'n eie terrein en navorsingsveld in die teologie. Die eksegetiese, historiese en dogmatologiese vakke werk met die inhoud van die reformatoriese geloof, met die kennis van God soos $\mathrm{Hy} \mathrm{Hom}$ in die Skrif openbaar. Praktiese Teologie werk met die gebeure, met die kenne van God, waar mense gevorm word om tot geloof te kom, en tot opbou van die geloof van die gemeente van Christus. Dit gaan in Praktiese Teologie om die oordrag van die geloof, die mediale (bemiddelende) handelings, of anders gesê, die kommunikasie van die boodskap van die Skrif in hierdie mediale handelings (vgl Heitink, 1993:115, 154). Praktiese Teologie het te make met die praksis van die christelike geloof in die kerk en in die getuienis van gelowiges op alle terreine van die lewe. Die praksis word egter deur teologiese teorieë gedra en gerig. Daarom is teologiese teorie en praksis ten nouste aan mekaar verbind - albei kante van 'n munt, in 'n bipolêre spanning (vgl. Josuttis, 1974:267). In hierdie paragraaf word die benaderings van Van der Ven, Dingemans, Zerfass en Heitink oorsigtelik bespreek.

Van der Ven werk met 'n empiriese benadering (Van der Ven, 1990; 1993). Sy teologiese invalshoek is Rooms-Katoliek. Sy doel is om die ideaal van teologiese teorieë empiries by kerklidmate en gewone mense te toets met die vraag of die praksis van die teorie verskil (Van der Ven, 1985). Hy interpreteer die begrip handelingswetenskap sterk na sy empiriese kant toe met harde, kwantitatiewe, empiries-analitiese ondersoeke. Hy noem die vak Empiriese Teologie (Van der Ven, 1990; vgl. Dingemans, 1996:42). Praktiese teoloë het teen die begin van die tagtigerjare van die vorige eeu die resultate van die sosiale wetenskappe gebruik om die praksis te ondersoek. Van der Ven lewer hewige kritiek daarop. Die invalshoeke van hulle 
ondersoeke word deur teorieë gerig wat vreemd aan die teologie is. Daarom doen hy self, as teoloog, ' $n$ empiriese ondersoek (Van der Ven, 1990; Dingemans, 1996:71). 'n Teoloog spit anders as 'n sosiale wetenskaplike met dieselfde graaf. Hy het die empiriese metodes bemeester om self te kan gebruik.

Binne die kader van 'n hermeneuties-kommunikatiewe praksis (op voetspoor van Gadamer en veral Ricoeur) in sy empiriese ondersoeke-ontwerp ondersoek hy bestaande teologiese teorieë met empiriese ondersoeke om vas te stel of die teorie ook so by mense aan wie die evangelie gekommunikeer word, funksioneer of nie. Hy sien die handelings in ons dissipline as kommunikatiewe handelings op voetspoor van Habermas. Die bestaande teologiese teorieë wat oor 'n bepaalde aspek in omloop is, soos byvoorbeeld die verstaan van God, word beskryf, in konsepte saamgevat en in 'n konseptuele raamwerk opgestel. Die konsepte word voorts in 'n vraelys geoperasionaliseer in vrae en formulerings wat gewone mense kan verstaan. Die vraelyste se antwoorde word statisties ontleed met die mees gesofistikeerde analises. Die resultate word bespreek en aanwysings vir verbeterde praktykteorieë word gegee (vgl. Van der Ven et al., 2004). By reformatoriese teoloë kan daar nie van empiriese teologie gepraat word nie. Die empiriese werklikheid dreig dan om die kriterium van die Skrif te oorwoeker. Wat ons by Van der Ven kan leer, is die aanpak van 'n hermeneuties-kommunikatiewe praktiese teologie as handelingswetenskap waarin ons self die empiriese ondersoeke met ons eie invalshoek en teorieë kan doen. Ons verkies egter om van 'n teologiese handelingswetenskap te praat (vgl. Firet, 1987).

Dingemans werk met ' $n$ hermeneutiese benadering gebaseer op Gadamer en Ricoeur se hermeneutiese teorieë (Dingemans, 1996). Sy invalshoek is dié van 'n reformatoriese praktiese teoloog met 'n pneumatologiese stempel waarin 'n teologiese goue draad deur sy werk loop (vgl. Dingemans, 2000). Hy sien die kerk as die brug tussen die evangelie en eietydse mense en die moderne samelewing (Dingemans, 1996:211-228). Hy is sterk teen 'n handelingswetenskaplike benadering en empiriese ondersoeke in die vak gekant (vgl. sy kritiek teen Van der Ven soos aangehaal deur Dingemans, 1996:42-45, 69-73; vgl. ook Immink, 2003 se kritiek teen Van der Ven, hoewel hy empiriese ondersoeke omarm). Dingemans en Van der Ven is twee uiterstes in hulle benadering tot die vak. Na sy kritiek op die handelingswetenskaplike benadering en die empiriese komponent daarvan, stel hy sy suiwer hermeneutiese benadering wat hy as 'n prakties-teologiese korrelasieteorie sien (Dingemans, 
1996:125-228). Hy noem 'n literatuurondersoek 'n kwalitatiewe ondersoek (Dingemans, 1996:47). Vanuit ons verstaan van die reformatoriese teologie moet kritiek uitgespreek word teen Dingemans se gebruikmaking van die prosesteologie. Wat ons van hom kan leer, is sy hermeneutiese aanpak van die vak en sy pneumatologiese klem.

Die ontwikkeling van Zerfass se prakties-teologiese denke vind plaas teen die agtergrond van die denkklimaat van die sestigerjare van die twintigste eeu, waarin 'n fokusverskuiwing plaasvind na die konkreet-lewende mens en sy situasie (Jonker, 1983:18). Onder druk van maatskaplike kritiek van die sestigerjare moes gereageer, gereformeer en verander word op verskeie vlakke van die kerklike lewe (vgl. Zerfass, 1974:164). Die kritiese ingesteldheid van die mens tree op die voorgrond. Die inrigting van kerklike praktyke en tradisies wat jare lank as vanselfsprekend beskou en kritiekloos aanvaar is, word aan nuwe ondersoeke onderwerp. Zerfass (1974: 166) ontwerp 'n prakties-teologiese model wat hy omskryf as "ein handlungswissenschaftliches Modell der Korrektur christlich-kirchlicher Praxis". In 'n handelingswetenskaplike benadering - 'n benadering wat gedeel word met aangrensende wetenskappe wat ook menslike gedrag ondersoek - hou Praktiese Teologie hom nie noodwendig besig met die vraag wat en hoe iets is nie, maar eerder wat in die menslike handelingpraksis gebeur en hoe dit kan gebeur (vgl. Dingemans, 1996:41).

Dit is opvallend dat daar in die handelingswetenskaplike inrigting van Zerfass se model nie sprake is van eenrigtingverkeer wat bloot vanuit teorie na praksis gereël word nie, maar van 'n primêre beweging vanuit die praksis van uitdruklik menslike handelings via teorie na 'n nuwe, gekorrigeerde praksis. 'n Verdere waarneming uit die werking van Zerfass se model is dat die basiese beweging vanuit praksis, via teorie na nuwe praksis ingerig word in die konteks van wisselwerking en dan bepaald, hermeneutiese wisselwerking. In die proses van wisselwerking het die analise van die konkrete situasie 'n bepaalde hermeneutiese uitwerking op die teologiese tradisie. Die teologiese tradisie word opgeroep om sy denkmodelle en geldende norme vir handelings opnuut in oënskou te neem en te herinterpreteer. Aan die ander kant het die teologiese tradisie in die proses van wisselwerking ook 'n invloed op die manier waarop die geanaliseerde situasie in 'n bepaalde rigting gestuur word. Die geanaliseerde situasie het geen intrinsieke handelingsaanwysings nie, maar moet ten opsigte van die implikasies daarvan eers getoets word aan en gekonfronteer word met die oorleweringsaansprake van die kerklike tradisie. Die werking van Zerfass se model loop uit 
op 'n kringloop waarin die nuwe handelingspraksis opnuut getoets moet word en deur die proses van hermeneutiese wisselwerking verder gekorrigeer behoort te word. Die reformatoriese tema waarmee Praktiese Teologie hom besig hou, word in 'n sikliese benadering gegiet waarin die status quo voortdurend gekorrigeer word (vgl. Bäumler, 1976:90).

Vanuit ons verstaan van die reformatoriese teologie, sou dit moeilik wees om kritiekloos aansluiting te vind by 'n model vir die inrigting van 'n teorie-praksisverhouding waarin die vertrekpunt primêr in die handelingsdruk van die konkrete kerklike praksis geneem word, en nie in die spanning tussen die Skrifopenbaring en die konkrete praksis nie. 'n Teologiese teorie wat uitsluitlik daarop gerig is om 'n bepaalde handelingspraksis reg te stel, sou na ons oordeel ook nie verteenwoordigend wees van die volle draagwydte van die praktiesteologiese taak nie (vgl. De Wet, 2006:79).

Heitink verstaan onder Praktiese Teologie as handelingswetenskap die empiries-georiënteerde, teologiese teorie van die bemiddeling van die Christelike geloof in die praksis van die moderne samelewing (Heitink, 1993:18). Hy beskou Praktiese Teologie as 'n handelingswetenskap wat tot die menswetenskappe behoort. Dit is egter belangrik om daarvan kennis te neem dat dit vir hom in die Praktiese Teologie bepaald gaan om die handelings van God deur die bemiddelende diens van mense (Heitink, 1993:19). Hy onderskei drie perspektiewe in sy empiries-georiënteerde, teologiese teorie, naamlik die hermeneutiese perspektief, die strategiese perspektief en die empiriese perspektief. Hy beroep hom met die oog hierop op Habermas se teorie van die kommunikatiewe handelings en Ricoeur se interpretasieteorie wat die grondlyne vir sy prakties teologiese metodologie lewer. Hierin word die hermeneutiese (geesteswetenskaplike) en empiriese (natuurwetenskaplike) perspektiewe via die werkwoorde begryp en verklaar met mekaar verbind. Albei werkwoorde is medebepalend vir die eie karakter van Praktiese Teologie, wat geleë is in die strategiese perspektief soos aangedui word met die werkwoord verander. 'n Metodologiese weg word gevolg waarin 'n prakties-teologiese probleemstelling, waarin die spanning tussen tradisie en ervaring op 'n bepaalde punt getematiseer word, vanuit 'n hermeneutiese teorie geïnterpreteer word, met behulp van 'n empiriese teorie geanaliseer word en via 'n strategiese teorie vertaal word in terme van handelings (Heitink, 1993:106).

Volgens Dingemans (1996:56) kan Heitink se teoretiese oorwegings, met reg, 'n integrasiepoging genoem word waarin alle gangbare metodes in prakties-teologiese navorsing onder een noemer 
gebring wil word (vgl. Heitink, 1993:11, 107). Hy lê nadruk op die komplementêre karakter tussen 'n empiries-analitiese en 'n hermeneutiese benadering. Heitink se integratiewe benadering word weerspieël in die onlangse werk van Osmer (2008:4) waarin 'n viervoudige taak vir prakties-teologiese navorsing onderskei word, naamlik 'n deskriptief-analitiese taak (soos dit sy beslag kry deur die vraag "What is going on?"); 'n interpretatiewe taak (met as kernvraag "Why is it going on?"); 'n normatiewe taak (met as kernvraag "What ought to be going on?"); en 'n pragmatiese taak (met as strategiese vraag "How should we respond?").

Daar is aspekte ten opsigte van ons benadering tot die vak in bostaande bespreking waaruit ons kan leer. By Van der Ven kan ons die gebruik van empiriese navorsing van die praksis met gebruikmaking van die outeurs se eie teologiese teorieë met waardering oorneem. Dingemans se klem op 'n pneumatologiese perspektief op hierdie vak is van groot belang. Zerfass het ons bewus gemaak vir die korreksie van die praksis deur die interaksie daarmee vanuit ons teologiese tradisie en teologies-teoretiese aanpak. Heitink se bydrae tot ons benadering is die integrasie van die empiries-analitiese, die hermeneutiese en die strategiese aspekte van navorsing.

\section{Slot}

Die noodsaak van die verrekening van metateoretiese vertrekpunte in prakties-teologiese wetenskapsbeoefening is vanuit reformatoriese gesigspunt behandel ten opsigte van die waarnemingsperspektief van die werklikheid, die hermeneutiese proses wanneer handelings in die praksis verstaan, verklaar en verander word, en die aard en taak van wetenskapsbeoefening in ons vak. Dit is duidelik dat die uitkoms van 'n prakties-teologiese ondersoekprojek 'n eie stempel het wanneer 'n mens vanuit 'n reformatoriese vertrekpunt ondersoek doen.

\section{Geraadpleegde bronne}

BAARS, A. 2004. Om Gods verhewenheid en zijn nabijheid: de Drie-eenheid bij Calvijn. Kampen: Kok.

BÄUMLER, C. 1976. Probleme der Theoriebildung Praktischer Theologie. (In Zerfass, R. \& Greinacher, N., Reds. Einführung in die Praktische Theologie. München: Kaiser. S. 77-95.)

BROWNING, D.S. 1991. A fundamental practical theology. Minneapolis: Fortress.

BUDE, H. 2004. The art of interpretation. (In Flick, U., Von Kardorf, E. \& Steinke, I., eds. A companion to qualitative research. London: Sage. p. 321-325.) 
COCHRANE, J.R., DE GRUCHY, J.W. \& PETERSEN, R. 1991. In word and deed: towards a practical theology for social transformation. Pietermaritzburg: Cluster.

DE WET, F.W. 2006. Die aanwending van Rolf Zerfass se handelingswetenskaplike model in prakties-teologies teorievorming - 'n gereformeerde perspektief. In die Skriflig, 40(1):57-87.

DE WET, F.W. 2009. Die implikasies van 'n pneumatologies-bepaalde teoretiese raamwerk vir navorsingsmetodologie in prakties-teologiese wetenskapsbeoefening. In die Skriflig, 43(2):227-250.

DINGEMANS, G.D.J. 1996. Manieren van doen: inleiding tot de praktische theologie. Kampen: Kok.

DINGEMANS, G.D.J. 2000. De stem van de Roepende: pneumatheologie. Kampen: Kok.

DREHSEN, V. 2007. Praktische Theologie. (In Gräb, W. \& Weyel, B., Reds. Handbuch Praktische Theologie. Gütersloh: Gütersloher Verlagshaus. S. 174-187.)

DREYER, J.S. 2002. Theological normativity: ideology or utopia? Reflections on the possible contribution of empirical research. Practical theology in South Africa, 17(2):1-17.

FIRET, J. 1987. Spreken als een leerling: praktisch-theologische opstellen. Kampen: Kok.

GADAMER, H.-G. 1975. Wahrheit und Methode. 4. Aufl. Tübingen: Mohr.

GADAMER, H.-G. 1979. Truth and method. Trans. by W. Glen-Doepel. London: Sheed \& Ward.

GRENZ, S.J. 2004. Rediscovering the triune God: the trinity in contemporary theology. Minneapolis: Fortress.

HEITINK, G. 1993. Praktische theologie: geschiedenis, theorie, handelingsvelden. Kampen: Kok.

HÖFTE, B. 1990. Bekering en bevrijding: de betekenis van de latijnsamerikaanse theologie voor een praktisch-theologische basistheorie. Hilversum: Gooi \& Sticht.

IMMINK, F.G. 2003. In God geloven: een praktisch-theologische reconstructie. Zoetermeer: Meinema.

IMMINK, F.G. 2005. Faith - a practical-theological construction. Grand Rapids: Eerdmans.

JONKER, H. 1983. Theologische praxis - problemen, peilingen en perspektieven bij kenterend getij. Nijkerk: Callenbach.

JOSUTTIS, M. 1974. Praxis des Evangeliums zwischen Politik und Religion: Grundprobleme der Praktischen Theologie. München: Kaiser.

LOTZ, T.A. 2007. Zur Methodologie phänomenologisch-empirischer Theologie. (In Dinter, A., Heimbrock, H-G. \& Söderblom, K., Reds. Einführung in die Empirische Theologie. Göttingen: Vandenhoeck \& Ruprecht. S. 60-72.)

NEWPORT, J.P. 1998. The New Age Movement and the biblical worldview conflict and dialogue. Grand Rapids: Eerdmans.

OSMER, R.R. 2008. Practical Theology: an introduction. Grand Rapids: Eerdmans.

PIETERSE, H.J.C. 2010. Metatheoretical decisions for the grounded theory research of sermons on poverty and to the poor as listeners. Acta theologica, 30(2):113-129. 
REBEL, J.J. 1981. Pastoraat in pneumatologisch perspektief: een theologische verantwoording vanuit het denken van A.A. van Ruler. Kampen: Kok.

REICHERTZ, J. 2004. Abduction, deduction and induction in qualitative research. (In Flick, U., Von Kardorf, E. \& Steinke, I., eds. A companion to qualitative research. London: Sage. p. 159-164.)

RICOEUR, P. 1976a. Ideology, utopia, and faith. Berkeley: The center for Hermeneutical Studies in Hellenistic and Modern Culture. Protocol of the colloquy of the Center for Hermeneutical Studies in Hellenistic and Modern culture, p. 21-28.

RICOEUR, P. 1976b. Interpretation theory: discourse and the surplus of meaning. Fort Worth: Texas Christian University Press.

RICOEUR, P. 1992. Oneself as another. Trans. by K. Blamey. Chicago: University of Chicago Press.

TAYLOR, C. 2007. A secular age. Cambridge: Harvard University Press.

VAN DER VEN, J.A. 1985. Pastoraal tussen ideaal en werkelijkheid. Kampen: Kok.

VAN DER VEN, J.A. 1990. Entwurf einer empirischen Theologie. Kampen: Kok.

VAN DER VEN, J.A. 1993. Practical theology: an empirical approach. Kampen: Kok.

VAN DER VEN, J.A. 2010. Human rights or religious rules? Leiden: Brill.

VAN DER VEN, J.A., DREYER, J.S. \& PIETERSE, H.J.C. 2004. Religious socialisation and the ongoing quest for a human rights culture in South Africa. Practical theology in South Africa, 19(1):33-53.

VAN PELT, J.W. 1999. Pastoraat in trinitarisch perspectief - de samehang tussen trinitarische en antropologische aspecten in het pastoraat. Heerenveen: Groen.

VIAU, M. 1999. Practical theology - a new approach. Leiden: Brill.

ZERFASS, R. 1974. Praktische Theologie als Handlungswissenschaft. (In Klostermann, F. \& Zerfass, R., Reds, Praktische Theologie Heute. München: Kaiser/Grünewald. S. 164-177.)

\section{Kernbegrippe:}

hermeneutiese teorie

metateoretiese vertrekpunte in Praktiese Teologie

reformatoriese teologie

werklikheid, aard van die

wetenskaplike benadering

\section{Key concepts:}

hermeneutical theory

metatheoretical assumptions in Practical Theology

reality, nature

reformed theology

scientific approach 
